\title{
Influence of Occlusal Splint on Mandibular Movements in Patients with Bruxism: a Comparative Pilot Study
}

\section{Utjecaj terapije okluzijskom udlagom na kretnje donje čeljusti kod pacijenata s bruksizmom: usporedna pilot-studija}

\footnotetext{
${ }_{1}$ Private practice; PhD student, School of Dental Medicine, University of Zagreb, Croatia Privatna ordinacija; student doktorskog studija Stomatološkog fakulteta Sveučilišta u Zagrebu

2 Department of Prosthodontics, School of Dental Medicine, University of Zagreb, Croatia

Zavod za mobilnu protetiku Stomatološkog fakulteta Sveučilišta u Zagrebu

${ }^{3}$ Department of Oral Surgery, School of Dental Medicine, University of Zagreb, University Dental Clinic

Zavod za oralnu kirurgiju Stomatološkog fakulteta Sveučilišta u Zagrebu
}

\section{Abstract}

Objective: The objective of this pilot study was to examine the impact of occlusal splint treatment on mandibular border movements and the condyle position in subjects with bruxism. Material and methods: The study included 9 subjects diagnosed with bruxism (mean age 28.7) and 9 subjects in the control group (mean age 30.5). All subjects were adults, eugnathic, and with a dentoalveolar Angle Class I, without prosthetic restorations, previous or current orthodontic treatments, a systemic disease or previous surgical interventions in the temporomandibular joint. All experimental and control group subjects were provided with a standardized relaxation occlusal splint, which they wore for 8 weeks. During this time, an initial and three additional measurements of incisal opening (IO), left condyle opening (OLC), right condyle opening (ORC), left laterotrusion (LLI) and right laterotrusion (LRI) (after 2, 4 and 8 weeks) were performed using an Arcus Digamma II (Kavo) ultrasound device for mandibular movements recording. Using the same instrument, the condylar position during protrusion, left and right laterotrusion, and in the centric relation position (CR) was analyzed initially and after 8 weeks using the maximum intercuspation as reference point. Continuous variables were described using basic statistical parameters, and the statistical significance of differences between the variables was checked by the t-test and $x 2$ test $(p<0.05)$. Results: The values of IO, OLC, ORC, LLI and LRI increased after 8 weeks of wearing, with the highest increase for OLC, by $13.8 \%$. No statistically significant difference $(p<0.05)$ was found for any changes in movements. Changes in the condyle position during all movements and those in the CR were higher in the experimental group for 10 out of 14 measured parameters compared to the control group. A statistically significant difference was established for 5 out of 14 measured parameters after the occlusal splint treatment. Conclusions: The results of this pilot study have proven the influence of the occlusal splint treatment on mandibular border movements in subjects with bruxism by increasing the range of movements. Also the changes of the condyle position in subjects with bruxism were greater compared to those in healthy subjects.
Received: April 28, 2020

Accepted: August 24, 2020

Address for correspondence Josip Škaričić

Private practice in Split Student of doctortal study at School of Dental Medicine, University of Zagreb

josip.skaricic@gmail.com

Key words

Bruxism; Occlusal Splints; Mandibular Condyle

\section{Introduction}

Bruxism is a repetitive rhythmic activity of masticatory muscles characterized by teeth clenching or grinding and/or mandibular suppression (1). Although bruxism is not considered to be a disorder but a behavior that is both a risk and a protective factor, it still engages researchers and clinicians intensely (2). Clinical consequences of bruxism include tooth wear, temporomandibular disorders, headache and masticatory pain, especially after waking up, while bruxism as a protective factor occurs in obstructive sleep apnea, with all its consequences (2, 3). Because of its unclear etiology, the treatment of bruxism is complex, and it includes intraoral devices, pharmacotherapy, physical therapy, and behavioral therapy (4). Although there is no consensus on its exact clinical indications and ef-
Uvod

Bruksizam je ponavljajuća ritmička aktivnost žvačnih mišića koju karakterizira stiskanje ili škripanje zuba i/ili potiskivanje donje čeljusti (1). Iako se bruksizam ne smatra poremećajem nego ponašanjem koje može biti rizično, ali i zaštitni čimbenik, i dalje intenzivno zaokuplja istraživače i kliničare (2). Kliničke posljedice prouzročene bruksizmom mogu biti trošenje zuba, temporomandibularni poremećaji, glavobolja te bol žvačnih mišića, osobito nakon buđenja, a kao zaštitni čimbenik bruksizam se pojavljuje, sa svim kliničkim posljedicama, u slučaju opstruktivne apneje u snu $(2,3)$. Zbog nejasne etiologije terapija bruksizma je složena i sastoji se od intraoralnih naprava, farmakoterapije, fizikalne terapije te bihevioralne terapije (4). Iako nema konsenzusa o točnim klinič- 
fect, the occlusal splint fabrication is the most common kind of treatment for patients with bruxism (5). It protects from teeth damage during strong muscular jaw contractions, thus reducing orofacial pain at the same time (6). By knowing and considering other effects of occlusal splints, such as the placebo effect, changes in occlusal contacts, improvement of masticatory muscle function, changes in patient behavior, and new positioning of the condyle and/or joint disc, the mechanisms of their effect have not been fully investigated yet (7). Masticatory function research relies on the use of advanced technology and state-of-the-art devices. Arcus Digma II (ADII) is one of the devices the scientific and practical value of which, as well as the repeatability of measurements, have been validated through research $(8,9,10)$. ADII is an ultrasonic electronic device, a kinematic face bow with six degrees of freedom, which records condyle movement and position, as well as mandibular movements. Research into the effect of occlusal splint treatment in subjects with bruxism has shown its impact on changes in masticatory muscle activity, the incidence of bruxism, and quality of life. The results of research have shown a change in the range of mandibular movements in subjects with bruxism, however, no studies have been conducted so far regarding the changes in the value of mandibular movements in subjects with bruxism during and after the occlusal splint treatment (11-13). The condyle position in the temporomandibular joint has often been investigated, but as shown by Obrez and Gallo (13), only through the development of modern kinematic three-dimensional systems with six degrees of freedom it is possible to measure the condyle position and movement mathematically accurately. So far, the research in which such devices were used has confirmed that occlusal splint impacts the condyle position in a way that vertical displacement of the condyle between maximum intercuspation (MI) and centric relation (CR) is increased, while the horizontal and transversal condylar displacement show considerable variability $(11,12)$. The objective of this pilot study was to examine the impact of the occlusal splint treatment on mandibular border movements and the condyle position in subjects with bruxism. The study hypothesis was that there would be no difference both in limited mandibular movements and in the condyle position before and after the occlusal splint treatment in subjects with bruxism.

\section{Material and methods}

This pilot study included 9 subjects diagnosed with bruxism (mean age 28.7) and 9 control group subjects (mean age 30.5). The subjects were adults, eugnathic, and with a dentoalveolar Angle Class I. The subjects with prosthetic restorations, previous or current orthodontic treatment, as well as with previous surgical interventions in the temporomandibular joint area and with a systemic disease, were excluded from the study. The study was conducted in Split recruiting the subjects from the entire southern Croatia. After clinical examination, the subjects with symptoms and signs of bruxism or temporomandibular disorders (TMD) completed the "Bruxism Diagnostic Questionnaire" and the "Diagnostic Criteria for Temporomandibular Disorders Criterion" (DC/TMD) - Axis I (14-16). "Bruxism Diagnostic Questionnaire" $(14,15)$ consisted of 6 yes/no kim indikacijama i načinu djelovanja, izrada okluzijske udlage najčešća je vrsta terapije u liječenju pacijenata $s$ dijagnozom bruksizma (5). Služi za zaštitu zuba od oštećenja tijekom snažnih mišićnih kontrakcija čeljusti te istodobno smanjuje orofacijalnu bol ako je prisutna (6). Poznajući i uzimajući u obzor i druge učinke okluzijske udlage, poput placebo učinka, promjena u okluzijskim dodirima, poboljšanja funkcije žvačnih mišića, promjene u ponašanju pacijenata te novog pozicioniranja kondila i/ili zglobne pločice, mehanizam njezina djelovanja nije u cijelosti istražen (7). $\mathrm{U}$ istraživanjima analize funkcije žvačnog sustava primjenjuju se napredna tehnologija i suvremeni uređaji. Jedan od uređaja kojemu je u istraživanjima potvrđena znanstvena i praktična vrijednost te ponovljivost mjerenja jest Arcus Digma II (ADII) $(8,9,10)$. ADII je ultrazvučni elektronički uređaj, kinematski obrazni luk sa šest stupnjeva slobode koji u realnom vremenu registrira kretnje i položaj kondila te kretnje donje čeljusti. Istraživanja koja su pratila učinak terapije okluzijskom udlagom kod ispitanika s bruksizmom pokazala su njezin utjecaj na promjene aktivnosti žvačnih mišića, učestalost epizoda bruksizma te kvalitetu života. Rezultati tih istraživanja sugeriraju promjenu u opsegu kretnji donje čeljusti kod ispitanika s bruksizmom, no dosad nije provedeno istraživanje vezano za promjene vrijednosti kretnji donje čeljusti kod ispitanika s bruksizmom tijekom terapije udlagom i nakon nje (11 - 13). Položaj kondila $\mathrm{u}$ temporomandibularnom zglobu često se istraživao, no kako navode Obrez i Gallo (13), tek nakon pojave suvremenih kinematskih trodimenzionalnih sustava sa šest stupnjeva slobode mogu se matematički precizno izmjeriti položaj i kretnje kondila. U dosadašnjim istraživanjima s tim uređajima ustanovljeno je da terapija okluzijskom udlagom utječe na položaj kondila tako što povećava vertikalni pomak kondila između maksimalne interkuspidacije (MI) i centrične relacije (CR), dok iznosi horizontalnog i transverzalnog pomaka kondila pokazuju veliku disperziju rezultata $(11,12)$. Svrha ovog pilotistraživanja bila je ispitati utjecaj terapije okluzijskom udlagom na granične kretnje donje čeljusti te položaj kondila kod ispitanika s bruksizmom. Hipoteza je bila da ne postoji razlika u graničnim kretnjama donje čeljusti i u položaju kondila prije terapije okluzijskom udlagom i poslije nje kod ispitanika s bruksizmom.

\section{Materijal i postupci}

U pilot-istraživanje bilo je uključeno 9 ispitanika s dijagnosticiranim bruksizmom (srednja dob 28,7 godine) i 9 ispitanika u kontrolnoj skupini (srednja dob 30,5 godine). Svi su bili punoljetni, eugnati $s$ dentoalveolarnom klasom I prema Angleu. Iz istraživanja su bili isključeni oni s postojećim protetičkim radovima, prijašnjom ili sadašnjom ortodontskom terapijom, prijašnjim kirurškim zahvatima u području temporomandibularnog zgloba te nekom od sistemskih bolesti. Istraživanje se obavljalo u Splitu, a pacijenti su potjecali iz južnog dijela Hrvatske. Nakon kliničkog pregleda ispitanici sa simptomima i znakovima bruksizma ili temporomandibularnog poremećaja (TMP-a) ispunili su Upitnik za dijagnostiku bruksizma te Dijagnostički kriterij za istraživanje temporomandibularnih poremećaja (DKI/TMP) - Os I 
questions, and if the subject answered two questions positively, the bruxism was diagnosed. DC/TMD -Axis I Questionnaire was used to find end exclude the subjects with TMD. The subjects diagnosed with bruxism based on their medical history, clinical examination, and questionnaire results were classified into the experimental group, while the subjects with TMD were excluded from the study. The subjects without symptoms and signs of bruxism and TMD were classified into the control group. Each subject signed the informed consent approved by the Ethics Committee of the School of Dental Medicine, University of Zagreb. The examiner standardization and repeatability of measurements were ensured in a way that all the measurements were made by the same examiner, who had received training and calibration instructions for the ADII ultrasound device. Five initial measurements were carried out on the first two subjects each. For the mandibular border movement analysis, the coefficient of variation amounted to a maximum of $0.9 \%$, while for the condylar position analysis the maximum value was $5 \%$. The study was conducted in a way that an occlusal splint was made for each subject of the experimental and control group using a standardized procedure, based on the values obtained with the three-dimensional kinematic face bow (ADII). After taking alginate impressions of the upper and lower jaws (Aroma Fine Plus, GC, Japan), stone casts were made and a paraocclusion tray (Unitray, Polident, Slovenia) used later for all measurements was made on the lower cast. The upper jaw position was registered using the occlusal tray with upper teeth silicone impressions (Optosil, Heraeus, Germany), after which the paraocclusion tray was attached to the lower dental arch using a temporary restorative material (Structur 2 SC, Voco, Germany), and the initial measurement was started. The subjects were positioned in the way that the Frankfurt horizontal plane was parallel to the floor, making a $90^{\circ}$ angle with the back of a chair. Using the KTS ("Kavo Transfer System") module on the ADII device, each subject performed three protrusion movements and the right and left laterotrusions, guided by occlusal contacts. According to the movements performed, the program calculated and displayed values for each subject for left and right condylar path inclination (SCI), left and right Bennett angle (BK), left and right immediate lateral displacement (ISS), incisal guidance angle (KIV) and left and right lateral anterior guidance angle (KLV). Centric relation (CR) registration was taken using an acrylic carrier with a deprogrammer (jig), lateral registration made of composite thermoplastic material (Bite Compound, GC, Japan), and by using a chin point guidance technique. Stone casts were articulated into a fully adjustable articulator (Protar Evo 7, Kavo, Biberach, Germany) using a transfer table ("Arcus Digma bite fork holder") and the CR registration. The articulator was individualized according to the previously obtained parameters (SCI, BK, ISS, KIV and KLV). Occlusal splints were made on the upper cast by a standardized procedure of cold polymerized acrylate application (Resil-S, Erkodent, and Pfalzgraffenweiler, Germany) onto a vacuum-drawn film. Occlusal contacts of the occlusal splint and the antagonist teeth were established according to the rule of mutually protected occlusion in static occlusion and according to the rule of canine-guided occlusion in dynamic occlusion. The splints were handed over to the subjects who were instruct-
(14 - 16). Upitnik za dijagnostiku bruksizma $(14,15)$ sastoji se od $6 \mathrm{da} /$ ne pitanja te ako ispitanik odgovori pozitivno na dva, dijagnosticira se bruksizam. DKI/TMP - Os I je upitnik na temelju kojega su isključeni ispitanici s TMP-om. Ispitanici kojima je na temelju anamneze, kliničkoga funkcijskog pregleda i rezultata upitnika dijagnosticiran bruksizam, svrstani su u ispitnu skupinu, a oni kojima je dijagnosticiran TMP isključeni iz istraživanja. Ispitanici bez simptoma i znakova bruksizma te TMP-a svrstani su u kontrolnu skupinu. Svaki ispitanik potpisao je informirani pristanak koji je odobrilo Etičko povjerenstvo Stomatološkog fakulteta Sveučilišta u Zagrebu. Standardizacija ispitivača i ponovljivost mjerenja osigurana je tako da je sva mjerenja obavio isti ispitivač koji je prošao edukaciju i kalibraciju rukovanja ultrazvučnim uređajem ADII te je za prva dva ispitanika provedeno po pet inicijalnih mjerenja. Za ispitivanje graničnih kretnji mandibule koeficijent varijacije iznosio je maksimalno $0,9 \%$, a za promjene položaja kondila i maksimalno $5 \%$. Istraživanje je provedeno na način da je za sve ispitanike ispitne i kontrolne skupine izrađena okluzijska udlaga standardiziranim postupkom na temelju vrijednosti dobivenih trodimenzionalnim kinematskim obraznim lukom (ADII). Nakon uzimanja alginatnog otiska gornje i donje čeljusti (Aroma Fine Plus, GC, Japan) izliveni su sadreni modeli te je na donjem modelu izrađena paraokluzijska žlica (Unitray, Polident, Slovenija) koja je korištena za sva mjerenja. Položaj gornje čeljusti registriran je okluzijskom žlicom s otiscima gornjih zuba u silikonu (Optosil, Heraeus, Njemačka) nakon čega je paraokluzijska žlica pričvršćena za donji zubni niz materijalom za izradu privremenih nadomjestaka (Structur 2 SC, Voco, Njemačka) te se pristupilo inicijalnom mjerenju. Ispitanik je namješten tako da je frankfurtska horizontalna ravnina bila paralelna s podom, a naslon stolca s njim činio je kut od $90^{\circ}$. S pomoću modula KTS (Kavo Transfer System) na uređaju ADII svaki ispitanik je učinio tri kretnje protruzije te desne i lijeve laterotruzije koje su bile vođene okluzijskim dodirima. Prema tim kretnjama program je izračunao i prikazao vrijednosti za svakog ispitanika za lijevi i desni kut nagiba kondilne staze (SCI), lijevi i desni Bennettov kut (BK), lijevi i desni imedijatni pomak u stranu (ISS), kut incizalnog vođenja (KIV) te lijevi i desni kut lateralnog prednjeg vođenja (KLV). Zatim je uzet registrat centrične relacije (CR) korištenjem akrilatnog nosača $s$ deprogramatorom (jigom), lateralnim registratom iz kompozicijskog termoplastičnog materijala (Bite Compound, GC, Japan) te korištenjem tehnike vođenja brade. Sadreni modeli artikulirani su u potpuno prilagodljivi artikulator (Protar Evo 7, Kavo, Biberach, Njemačka) s pomoću prijenosnog stolića (ArcusDigma bite fork holder) i registrata CR. Artikulator je individualiziran prema prethodno dobivenim parametrima (SCI, BK, ISS, KIV i KLV). Okluzijske udlage izrađene su na gornjem modelu standardiziranim postupkom nanošenjem hladnopolimerizirajućeg akrilata (Resil-S, Erkodent, Pfalzgraffenweiler, Njemačka) na vakuumski vučenu foliju. Okluzijski dodiri okluzijske udlage i zuba nasuprotne čeljusti uspostavljeni su prema pravilu uzajamno zaštićene okluzije u statičkoj okluziji te prema pravilu očnjakom vođene okluzije u dinamičkoj okluziji. Udlage su predane ispitanicima uz uputu da ih nose 8 tjedana i to svaki 
ed to wear them at least 10 hours a day for 8 weeks. The following measurements were performed at the beginning of the treatment as the splints were handed over: ( 0 week) and after 2 , 4 and 8 weeks of wearing (1st, 2nd and 3rd control). Limited mandibular movements were measured in the Motion Analysis (MA) module of the ADII device. After detailed explanation and training, the subjects performed maximum mouth opening and closing, maximum left and right laterotrusion (occlusion-guided movements), and Posselt's border movements in the frontal and sagittal plane. After the movements were performed, the software calculated the values (in millimeters) for sagittal incisal point movements during all movements, as well as the values of condyle movements during mouth opening/ closing. The condyle position was measured in the "EPA-Electronic Position Analysis of the Mandibular Position" (EPA) module of the ADII device. The device was used for the subjects' bite registration at maximum intercuspation (IKP), registered as a reference point. Subsequently, the subjects performed the maximum protrusion and both laterotrusions. At the end of all movements, the subjects inserted the splint into the mouth and bit into it, making registration of the centric relation position. The software calculated the condyle position with respect to the reference position (in millimeters) in three spatial axes: $\mathrm{x}$-axis - anteroposteriorly, $\mathrm{y}$-axis - superoinferiorly, and zaxis - mediolaterally. These values were transferred to another program (Microsoft Excel, Microsoft Corporation, Redmond, USA) using Microsoft Copy Points option for further processing. The procedure was performed at the beginning of treatment $(0$ weeks) and after 8 weeks ( 3 rd control). For statistical analysis, STATISTICA 12.0 software package was used. The frequencies and percentages were calculated for each categorical variable. Continuous variables were described using basic statistical parameters (mean value, standard deviation, coefficient of variation, and standard error of mean, median, minimum and maximum value). Normality of the data was checked by the Shapiro-Wilks W test and Homogeneity of variance by the Levene test. In case of deviation from normality, the results were mathematically normalized. The difference between two groups of continuous, normally distributed variables was checked by the $t$-test and for more than two groups by the one way analysis of variance, followed by the Newman-Keuls test in case that the analysis of variance showed a significant difference. The difference between percentages was checked by the $\chi 2$ test. In all calculations the significance level was set to $\mathrm{p}<0.05$.

\section{Results}

The basic statistical parameters for incisal opening (IO), opening of left condyle (OLC), opening of right condyle (ORC), left laterotrusion (LLI) and right laterotrusion (LRI) measured at baseline (0) and after 2, 4 and 8 weeks of treatment are presented in Figure 1. In case of incisal opening, only a slight increase was observed after two weeks of the treatment $(0.3 \%)$, while the increase after four and eight weeks amounted to $3.4 \%$ and $5.8 \%$, respectively (Table 1). Among five measured parameters, opening of left condyle showed the highest percentage of increase following eight weeks of the treatment compared to the baseline (13.8\%). Other parameters showed a somewhat lower increase after eight weeks compared to the dan najmanje 10 sati. Sljedeća mjerenja obavljena su na samom početku terapije pri predaji udlage ( 0 tjedana) te nakon 2, 4 i 8 tjedana nošenja udlage (1, 2 i 3 kontrola). Granične kretnje donje čeljusti mjerene su u modulu Motion Analysis (MA) uređaja ADII. Nakon detaljnog objašnjenja i uvježbavanja ispitanik je obavio maksimalno otvaranje i zatvaranje usta, maksimalnu lijevu i desnu laterotruziju (kretnje vođene okluzijom) te Posseltove granične kretnje u frontalnoj i sagitalnoj ravnini. Nakon tih kretnji softver je izračunao vrijednosti (u milimetrima) za kretnje sagitalne incizalne točke pri svim kretnjama te vrijednosti kretnji kondila tijekom otvaranja/zatvaranja usta. Položaj kondila mjeren je u modulu EPA-Electronic Position Analysis of the Mandibular Position (EPA) uređaja ADII. Zagriz ispitanika u maksimalnoj interkuspidaciji (IKP) na uređaju je registriran kao referentna točka. Nakon toga je ispitanik učinio kretnju maksimalne protruzije te obje laterotruzije. Poslije završetka svih kretnji ispitanik je postavio udlagu u usta te zagrizao kada je registriran položaj centrične relacije (CR). Softver je izračunao položaj kondila u odnosu prema referentnom položaju (u milimetrima) u tri prostorne osi: x osi - anteroposteriorno, y osi - superoinferiorno te z osi - mediolateralno. Navedene vrijednosti su s pomoću opcije Microsoft Copy Points prebačene u drugi program (Microsoft Excel, Microsoft Corporation, Redmond, SAD) na daljnju obradu. Postupak je obavljen i prije početka terapije ( 0 tjedana) i nakon 8 tjedana (3. kontrola). Za statističku analizu korišten je programski paket STATISTICA 12.0. Za svaku kategoričku varijablu izračunati su učestalost i postotak. Kontinuirane varijable opisane su na temelju osnovnih statističkih parametara (srednja vrijednost, standardna devijacija, koeficijent varijacije, standardna pogreška srednje vrijednosti, medijan, minimalna i maksimalna vrijednost). Normalnost podataka provjerena je Shapiro-Wilksovim W-testom, a homogenost varijance Leveneovim testom. U slučaju odstupanja od normalnosti rezultati su matematički normalizirani. Razlika između dviju skupina kontinuiranih, normalno raspodijeljenih varijabli provjerena je t-testom, a za više od dvije skupine jednosmjernom analizom varijance, a zatim Newman-Keulsovim testom u slučaju da je analiza varijance pokazala značajnu razliku. Razlika između postotaka provjerena je testom $\chi 2$. U svim analizama značajnost je postavljena na $\mathrm{p}<0,05$.

\section{Rezultati}

Osnovni statistički parametri za incizalno otvaranje (IO), otvaranje lijevog kondila (OLC), otvaranje desnog kondila (ORC), lijevu laterotruziju (LLI) i desnu laterotruziju (LRI) izmjereni prije početka terapije (0) i nakon 2, 4 i 8 tjedana terapije prikazani su na slici 1 . Nakon dva tjedna terapije utvrđeno je samo blago povećanje incizalnog otvaranja (s 43,69 \pm $8,93 \mathrm{~mm}$ na 43,81 $\pm 9,06 \mathrm{~mm}$ ) od $0,3 \%$, povećanje nakon četiri tjedana iznosilo je 3,4 \%, a poslije osam tjedana 5,8 \% (tablica 1.). Od pet izmjerenih parametara, otvaranje lijevog kondila imalo je najveći postotak povećanja nakon osam tjedana terapije $(13,8 \%)$ u odnosu prema početnoj vrijednosti. Za druge je parametre zabilježeno nešto manje povećanje na- 


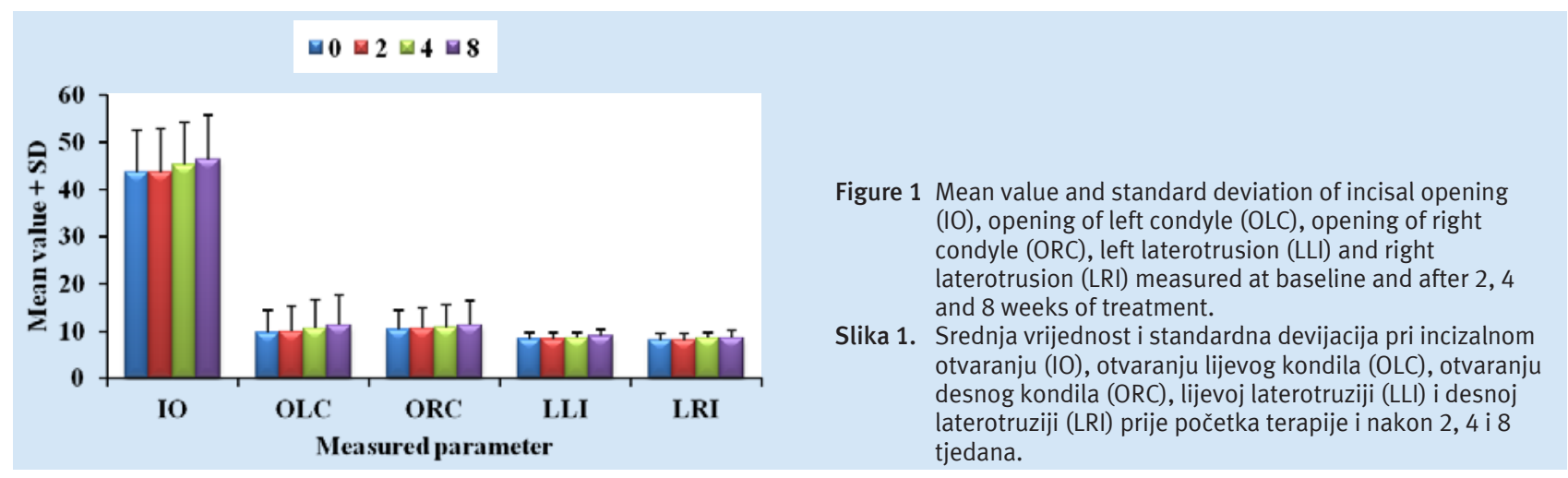

Table 1 Percentage of increase (decrease) of incisal opening (IO), opening of left condyle (OLC), opening of right condyle (ORC), left laterotrusion (LLI) and right laterotrusion (LRI) after different time periods compared to baseline.

Tablica 1. Postotak povećanja (smanjenja) incizalnog otvaranja (OI), otvaranja lijevog kondila (OLC), otvaranja desnog kondila (ORC), lijeve laterotruzije (LLI) i desne laterotruzije (LRI) nakon 2, 4 i 8 tjedana terapije u odnosu prema početnom stanju.

\begin{tabular}{c|c|c|c|c|c|c}
\hline Time (wks) $・$ Vrijeme terapije (tjedni) & IO & OLC & ORC & LLI & LRI \\
\hline 2 & 0.3 & 2.9 & 2.4 & 0.9 & -0.3 \\
\hline 4 & 3.4 & 7.8 & 4.4 & 2.7 & 4.1 \\
\hline 8 & 5.8 & 13.8 & 8.9 & 7.5 & 5.7 \\
\hline
\end{tabular}

initial value: opening of right condyle total increase of $8.9 \%$, left laterotrusion, $7.5 \%$ and the right laterotrusion total increase of $5.7 \%$. Although all five measured parameters showed an increase following eight weeks of the treatment, the analysis of variance showed no significant difference with respect to treatment duration. The basic statistical parameters for the position of the condyle in protrusion in the experimental and control group at baseline and after eight weeks of treatment are presented in Table 2. In the case of protrusion, $\mathrm{X}$ position increased both in the experimental and the control group after eight weeks of treatment. Considering $\mathrm{Y}$ and $\mathrm{Z}$ positions in protrusion, there were no changes in the experimental group following the treatment, while a slight decrease was observed kon osam tjedana terapije u usporedbi s početnom vrijednosti: za otvaranje desnog kondila ukupno povećanje iznosilo je $8,9 \%$, za lijevu laterotruziju $7,5 \%$, a za desnu laterotruziju $5,7 \%$. Iako je povećanje ustanovljeno za svih pet izmjerenih parametara nakon osam tjedana terapije, analiza varijance nije pokazala statistički značajnu razliku između trajanja terapije. Osnovni statistički parametri za položaj kondila u protruziji u ispitnoj i kontrolnoj skupini prije početka terapije i nakon osam tjedana prikazani su u tablici 2. Kod protruzije X položaj se povećao i u ispitnoj i u kontrolnoj skupini nakon osam tjedana terapije. Za Y i Z položaje u protruziji nije bilo promjena $\mathrm{u}$ ispitnoj skupini nakon terapije, a u kontrolnoj skupini utvrđeno je blago smanjenje Y i Z položaja. Kod

Table 2 Basic statistical parameters for the position of the condyle in protrusion in the experimental (E) and control (C) group at baseline (0) and after eight weeks (8) of the treatment. X-mean value; SD-standard deviation, CV-coefficient of variation; SE-standard error of mean value; $M$-median

Tablica 2. Osnovni statistički parametri položaja kondila u protruziji u ispitnoj (E) i kontrolnoj skupini (C) prije početka (0) i nakon osam (8) tjedana terapije. X-srednja vrijednost; SD-standardna devijacija, CV-koeficijent varijacije; SE-standardna pogreška srednje vrijednosti; M-medijan

\begin{tabular}{|c|c|c|c|c|c|c|c|c|c|}
\hline $\begin{array}{c}\text { Movement • Kretnja } \\
(\mathrm{mm})\end{array}$ & $\begin{array}{c}\text { Treatment } \\
\text { time (wks) } \\
\text { Vrijeme terapije } \\
(\text { tjedni) }\end{array}$ & $\begin{array}{l}\text { Group • } \\
\text { Skupina }\end{array}$ & $\overline{\mathbf{X}}$ & SD & $\mathrm{CV}$ & SE & M & Min. & $\begin{array}{l}\text { Max. • } \\
\text { Maks. }\end{array}$ \\
\hline \multirow{4}{*}{$X($ fwd $\bullet$ naprijed $)$} & 0 & E & 1.68 & 1.04 & 0.62 & 0.24 & 1.40 & 0.40 & 4.10 \\
\hline & 0 & $\mathrm{C}$ & 2.17 & 0.68 & 0.31 & 0.16 & 2.20 & 1.00 & 3.30 \\
\hline & 8 & $\mathrm{E}$ & 2.06 & 1.10 & 0.53 & 0.26 & 1.75 & 0.50 & 4.00 \\
\hline & 8 & $\mathrm{C}$ & 2.30 & 0.69 & 0.30 & 0.16 & 2.40 & 1.10 & 3.50 \\
\hline \multirow{4}{*}{ Y (up • gore) } & 0 & $\mathrm{E}$ & -1.15 & 1.22 & -1.06 & 0.29 & -0.95 & -3.40 & 1.20 \\
\hline & 0 & $\mathrm{C}$ & -1.81 & 1.08 & -0.60 & 0.26 & -2.05 & -3.20 & 0.40 \\
\hline & 8 & $\mathrm{E}$ & -1.14 & 1.69 & -1.48 & 0.40 & -1.55 & -3.00 & 2.80 \\
\hline & 8 & $\mathrm{C}$ & -1.66 & 1.05 & -0.63 & 0.25 & -2.00 & -3.10 & 0.50 \\
\hline \multirow{4}{*}{$\mathrm{Z}(\mathrm{rt})$} & 0 & $E$ & 0.24 & 0.43 & 1.79 & 0.10 & 0.10 & -0.60 & 1.00 \\
\hline & 0 & $\mathrm{C}$ & -0.28 & 0.36 & -1.29 & 0.09 & -0.40 & -0.70 & 0.60 \\
\hline & 8 & $E$ & 0.24 & 0.28 & 1.17 & 0.07 & 0.20 & -0.20 & 0.70 \\
\hline & 8 & $\mathrm{C}$ & -0.21 & 0.35 & -1.67 & 0.08 & -0.40 & -0.50 & 0.70 \\
\hline
\end{tabular}


for both $\mathrm{Y}$ and $\mathrm{Z}$ positions in the control group. In the case of right laterotrusion (Table 3), $\mathrm{X}$ position increased both in the experimental and control group after eight weeks of treatment. However, this increase is higher in the experimental group. Considering Y position, the experimental group showed a slight increase at the end of the treatment, while the control group showed almost no changes. For $\mathrm{Z}$ movement, both groups showed almost no changes compared to the baseline. $\mathrm{X}$ and $\mathrm{Y}$ position of the condyle in left laterotrusion (Table 4) increased both in the experimental and control group after eight weeks of treatment. Z movement increased from $-0.02 \mathrm{~mm}$ to $0.11 \mathrm{~mm}$ in the experimental group, while there were no changes in the control group. $\mathrm{X}$ position of the condyle in centric relation decreased from $0.33 \mathrm{~mm}$ to 0.26 desne laterotruzije (tablica 3.) X položaj se povećao i u ispitnoj i u kontrolnoj skupini nakon osam tjedana terapije. No povećanje je bilo veće u ispitnoj skupini. Za Y položaj u ispitnoj je skupini uočeno blago povećanje na kraju terapije, a u kontrolnoj nije bilo gotovo nikakvih promjena. Za Z položaj u objema skupinama nije bilo gotovo nikakvih promjena u odnosu prema početnom stanju. X i Y položaj kondila u lijevoj laterotruziji (tablica 4) povećao se i u ispitnoj i kontrolnoj skupini nakon osam tjedana terapije. $Z$ kretnja povećala se $\mathrm{s}-0,02 \mathrm{~mm}$ na $0,11 \mathrm{~mm}$ u ispitnoj skupini, a u kontrolnoj nije bilo promjena. Za X položaj kondila u centričnoj relaciji utvrđeno je smanjenje s $0,33 \mathrm{~mm}$ na $0,26 \mathrm{~mm}$ nakon osam tjedana terapije. $\mathrm{U}$ istom je vremenu u kontrolnoj skupini zabilježeno blago povećanje $s 0,21 \mathrm{~mm}$ na $0,23 \mathrm{~mm}$ (tablica

\begin{tabular}{|c|c|c|c|c|c|c|c|c|c|}
\hline $\begin{array}{cl}\text { Table 3 } & \text { Basic statistica } \\
& \text { at baseline (0) } \\
\text { standard error } \\
\text { Tablica 3. } \\
\text { Osnovni statis } \\
\text { nakon osam (8 } \\
\text { vrijednosti; } M-\end{array}$ & $\begin{array}{l}\text { rameters for the } \\
\text { after eight weeks } \\
\text { eaan value; M-me } \\
\text { parametri položa } \\
\text { dana. X-srednja v } \\
\text { ijan }\end{array}$ & $\begin{array}{l}\text { ition of th } \\
\text { of the tre } \\
\text { kondila u c } \\
\text { dnost; SD }\end{array}$ & $\begin{array}{l}\text { nent. X- } \\
\text { ndardn later } \\
\text { ndardn }\end{array}$ & $\begin{array}{l}\text { ziji u is } \\
\text { ijacija }\end{array}$ & standa & $\begin{array}{l}\text { viation } \\
\text { Inoj s| } \\
\text { arijacij }\end{array}$ & $\begin{array}{l}\text { (C) prij } \\
\text { standa }\end{array}$ & četka t & $\begin{array}{l}\text { P } \\
\text { SE- } \\
\text { ije (0) i } \\
\text { rednje }\end{array}$ \\
\hline $\begin{array}{l}\text { Movement } \bullet \text { Kretnja } \\
(\mathbf{m m})\end{array}$ & $\begin{array}{c}\text { Treatment } \\
\text { time (wks) } \\
\text { Vrijeme terapije } \\
(\text { tjedni) }\end{array}$ & $\begin{array}{l}\text { Group • } \\
\text { Skupina }\end{array}$ & $\overline{\mathbf{X}}$ & SD & CV & SE & $\mathbf{M}$ & Min. & $\begin{array}{l}\text { Max. } \\
\text { Maks. }\end{array}$ \\
\hline \multirow{4}{*}{$X($ fwd $•$ naprijed $)$} & 0 & E & 0.60 & 0.54 & 0.90 & 0.13 & 0.65 & -0.60 & 1.90 \\
\hline & 0 & $\mathrm{C}$ & 0.73 & 0.87 & 1.19 & 0.20 & 0.60 & -0.50 & 2.40 \\
\hline & 8 & E & 0.82 & 0.61 & 0.74 & 0.14 & 0.70 & -0.40 & 2.20 \\
\hline & 8 & $\mathrm{C}$ & 0.80 & 0.90 & 1.13 & 0.21 & 0.70 & -0.40 & 2.50 \\
\hline \multirow{4}{*}{ Y (up • gore) } & 0 & $\mathrm{E}$ & -0.39 & 0.94 & -2.41 & 0.22 & -0.10 & -2.00 & 0.90 \\
\hline & 0 & $\mathrm{C}$ & -0.39 & 1.01 & -2.59 & 0.24 & 0.00 & -2.00 & 1.00 \\
\hline & 8 & E & -0.15 & 1.06 & -7.07 & 0.25 & -0.10 & -2.00 & 1.40 \\
\hline & 8 & $\mathrm{C}$ & -0.38 & 1.02 & -2.68 & 0.24 & 0.00 & -2.00 & 1.00 \\
\hline \multirow{4}{*}{$\mathrm{Z}(\mathrm{rt})$} & 0 & $\mathrm{E}$ & 0.43 & 0.31 & 0.72 & 0.07 & 0.30 & 0.10 & 1.10 \\
\hline & 0 & $\mathrm{C}$ & 0.18 & 0.12 & 0.67 & 0.03 & 0.15 & 0.10 & 0.50 \\
\hline & 8 & $\mathrm{E}$ & 0.41 & 0.19 & 0.46 & 0.04 & 0.40 & 0.20 & 0.70 \\
\hline & 8 & $\mathrm{C}$ & 0.19 & 0.11 & 0.58 & 0.03 & 0.15 & 0.10 & 0.40 \\
\hline
\end{tabular}

\begin{tabular}{|c|c|c|c|c|c|c|c|c|c|}
\hline $\begin{array}{ll}\text { Table } 4 & \text { Basic statistic } \\
& \text { baseline (0) an } \\
\text { standard error } \\
\text { Tablica 4. } \\
\text { Osnovni statis } \\
\text { nakon osam (8 } \\
\text { vrijednosti; } M\end{array}$ & $\begin{array}{l}\text { rameters for the } \\
\text { ter eight weeks ( } 8 \\
\text { ean value; M-me } \\
\text { parametri položa } \\
\text { dana. X-srednja v } \\
\text { ijan }\end{array}$ & $\begin{array}{l}\text { ition of the } \\
\mathrm{f} \text { the treat } \\
\mathrm{n} \\
\text { dnostila u li } \\
\text { dno }\end{array}$ & $\begin{array}{l}\text { ndyle i } \\
\text { t. X-m } \\
\text { oj later } \\
\text { ndardr }\end{array}$ & $\begin{array}{l}\text { latero } \\
\text { alue; } \mathrm{S} \\
\text { iji u isp } \\
\text { ijacija }\end{array}$ & $\begin{array}{l}\text { on in the } \\
\text { andard } \\
\text { j (E) i ko } \\
\text { koeficije }\end{array}$ & $\begin{array}{l}\text { erimer } \\
\text { ation, } \mathrm{C} \\
\text { Inoj sk } \\
\text { arijacij }\end{array}$ & $\begin{array}{l}\text { E) and c } \\
\text { efficien } \\
\text { (C) prij } \\
\text {-standa }\end{array}$ & $\begin{array}{l}\text { ol (C) gr } \\
\text { ariation } \\
\text { setka te } \\
\text { pogreš }\end{array}$ & $\begin{array}{l}\text { at } \\
\text { je (0) i } \\
\text { rednje }\end{array}$ \\
\hline $\begin{array}{l}\text { Movement } \bullet \text { Kretnja } \\
(\mathrm{mm})\end{array}$ & $\begin{array}{c}\text { Treatment } \\
\text { time (wks) } \\
\text { Vrijeme terapije } \\
\text { (tjedni) }\end{array}$ & $\begin{array}{l}\text { Group } \\
\text { Skupina }\end{array}$ & $\overline{\mathbf{X}}$ & SD & $\mathrm{CV}$ & SE & M & Min. & $\begin{array}{l}\text { Max. } \\
\text { Maks. }\end{array}$ \\
\hline \multirow{4}{*}{$X($ fwd $\bullet$ naprijed $)$} & 0 & $\mathrm{E}$ & 0.58 & 0.68 & 1.17 & 0.16 & 0.55 & -0.60 & 2.30 \\
\hline & 0 & $\mathrm{C}$ & 0.77 & 0.79 & 1.03 & 0.19 & 0.80 & -0.50 & 2.30 \\
\hline & 8 & E & 0.77 & 0.77 & 1.00 & 0.18 & 0.75 & -0.20 & 2.30 \\
\hline & 8 & $\mathrm{C}$ & 0.83 & 0.79 & 0.95 & 0.19 & 0.80 & -0.40 & 2.40 \\
\hline \multirow{4}{*}{ Y (up• gore) } & 0 & E & -0.10 & 1.09 & -10.90 & 0.26 & -0.20 & -2.30 & 2.00 \\
\hline & 0 & $\mathrm{C}$ & -0.10 & 0.90 & -9.00 & 0.21 & 0.00 & -1.60 & 1.50 \\
\hline & 8 & $\mathrm{E}$ & 0.13 & 1.23 & 9.46 & 0.29 & -0.05 & -2.30 & 2.70 \\
\hline & 8 & $\mathrm{C}$ & -0.02 & 0.86 & -43.00 & 0.20 & 0.05 & -1.40 & 1.60 \\
\hline \multirow{4}{*}{$\mathrm{Z}$ (rt) } & 0 & E & -0.02 & 0.55 & -27.50 & 0.13 & 0.20 & -1.00 & 0.60 \\
\hline & 0 & $\mathrm{C}$ & -0.23 & 0.24 & -1.04 & 0.06 & -0.20 & -0.60 & 0.30 \\
\hline & 8 & $\mathrm{E}$ & 0.11 & 0.34 & 3.09 & 0.08 & 0.00 & -0.40 & 0.60 \\
\hline & 8 & $\mathrm{C}$ & -0.23 & 0.24 & -1.04 & 0.06 & -0.20 & -0.60 & 0.30 \\
\hline
\end{tabular}


$\mathrm{mm}$ following eight weeks of treatment. In the same period, the control group showed a slight increase from $0.21 \mathrm{~mm}$ to $0.23 \mathrm{~mm}$ (Table 5). After eight weeks Y position increased in the experimental group, and remained unchanged in the control group, while $Z$ position decreased in the experimental group, while almost no changes were observed in the control group. Table 1 presents the relative percentage of changes in the condyle position in protrusion, right and left laterotrusion and central relation in the experimental and control group after eight weeks compared to the baseline and the results of $\chi 2$ test. The only significant changes between those two groups in protrusion were observed for $\mathrm{Z}$ movement $(\mathrm{p}=0.0082)$. In right laterotrusion, a significant difference between the two groups was found for $Y$ movement $(\mathrm{p}<0.0001)$. A significant difference in left laterotrusion was observed for $\mathrm{Z}$ movement $(\mathrm{p}<0.0001)$ and in central relation for both $Y(\mathrm{p}<0.0001)$ and $\mathrm{Z}$ movement $(\mathrm{p}=0.0005)$.
5). Nakon osam tjedana utvrđeno je povećanje $Y$ položaja i smanjenje $\mathrm{Z}$ položaja u ispitnoj skupini, u kontrolnoj nije bilo promjena. U tablici 1. prikazan je relativni postotak promjene položaja kondila u protruziji, desnoj i lijevoj laterotruziji i centričnoj relaciji u ispitnoj i kontrolnoj skupini nakon osam tjedana terapije u odnosu prema početku i rezultatima $\chi 2$ testa. Između tih dviju skupina ispitanika ustanovljene su za protruziju samo statistički značajne razlike za Z kretnju (p $=0,0082)$. Kod desne laterotruzije utvrđena je statistički značajna razlika između dviju skupina ispitanika za Y kretnju (p $<0,0001)$. Statistički značajna razlika kod lijeve laterotruzije uočena je za $Z$ kretnju $(p<0,0001)$, a u centričnoj relaciji i za $Y(p<0,0001)$ i za $Z$ kretnju $(p=0,0005)$. Table 5 Basic statistical parameters for the position of the condyle in centric relation in the experimental (E) and control (C) group at
baseline (0) and after eight weeks (8) of the treatment. X-mean value; SD-standard deviation, CV-coefficient of variation; SEstandard error of mean value; M-median

Tablica 5. Osnovni statistički parametri položaja kondila u centričnoj relaciji u ispitnoj (E) i kontrolnoj skupini (C) prije početka terapije (0) i nakon osam (8) tjedana. X-srednja vrijednost; SD-standardna devijacija, CV-koeficijent varijacije; SE-standardna pogreška srednje vrijednosti; $M$-medijan

\begin{tabular}{|c|c|c|c|c|c|c|c|c|c|}
\hline $\begin{array}{l}\text { Movement • Kretnja } \\
(\mathbf{m m})\end{array}$ & $\begin{array}{c}\text { Treatment } \\
\text { time }(\text { wks }) \\
\text { Vrijeme terapije } \\
(\text { tjedni) }\end{array}$ & $\begin{array}{l}\text { Group • } \\
\text { Skupina }\end{array}$ & $\overline{\mathbf{X}}$ & SD & $\mathrm{CV}$ & SE & M & Min. & $\begin{array}{l}\text { Max.• } \\
\text { Maks. }\end{array}$ \\
\hline \multirow{4}{*}{$X($ fwd $\bullet$ naprijed $)$} & 0 & $\mathrm{E}$ & 0.33 & 0.33 & 1.00 & 0.08 & 0.30 & -0.30 & 1.00 \\
\hline & 0 & $\mathrm{C}$ & 0.21 & 0.32 & 1.52 & 0.08 & 0.15 & -0.40 & 0.70 \\
\hline & 8 & $\mathrm{E}$ & 0.26 & 0.32 & 1.23 & 0.08 & 0.20 & -0.20 & 1.10 \\
\hline & 8 & $\mathrm{C}$ & 0.23 & 0.30 & 1.30 & 0.07 & 0.20 & -0.30 & 0.80 \\
\hline \multirow{4}{*}{ Y (up•gore) } & 0 & $\mathrm{E}$ & 0.07 & 0.63 & 9.00 & 0.15 & -0.05 & -0.80 & 1.30 \\
\hline & 0 & $\mathrm{C}$ & 0.11 & 0.37 & 3.36 & 0.09 & 0.20 & -0.60 & 0.70 \\
\hline & 8 & $E$ & 0.22 & 0.52 & 2.36 & 0.12 & 0.15 & -0.50 & 1.30 \\
\hline & 8 & $\mathrm{C}$ & 0.11 & 0.35 & 3.18 & 0.08 & 0.15 & -0.60 & 0.80 \\
\hline \multirow{4}{*}{$\mathrm{Z}(\mathrm{rt})$} & 0 & $\mathrm{E}$ & 0.14 & 0.60 & 4.29 & 0.14 & 0.10 & -0.50 & 1.70 \\
\hline & 0 & $\mathrm{C}$ & 0.08 & 0.06 & 0.75 & 0.02 & 0.10 & -0.10 & 0.10 \\
\hline & 8 & $\mathrm{E}$ & 0.08 & 0.50 & 6.25 & 0.12 & 0.00 & -0.30 & 2.00 \\
\hline & 8 & $\mathrm{C}$ & 0.07 & 0.07 & 1.00 & 0.02 & 0.10 & -0.10 & 0.10 \\
\hline
\end{tabular}

Table 6 Relative percentage of changes of condyle position in protrusion, right and left laterotrusion and central relation in the experimental and control group after eight weeks of treatment compared to the baseline and the results of $\chi 2$ test.

Tablica 6. Relativni postotak promjene položaja kondila u protruziji, desnoj i lijevoj laterotruziji i centričnoj relaciji u ispitnoj i kontrolnoj skupini nakon osam tjedana terapije $u$ odnosu prema početku i rezultatima $\chi 2$ testa

\begin{tabular}{|c|c|c|c|c|}
\hline & Movement $\bullet$ Kretnja & $\begin{array}{l}\text { Experimental • } \\
\text { Ispitna skupina }\end{array}$ & Control $\bullet$ Kontrolna skupina & $\mathbf{p}$ \\
\hline \multirow{3}{*}{ Protrusion $\bullet$ Protruzija } & $\mathrm{X}$ & 18.4 & 5.7 & 0.2394 \\
\hline & $\mathrm{Y}$ & 0.9 & 8.3 & 0.4143 \\
\hline & $\mathrm{Z}$ & 0.0 & 25.0 & $0.0082^{*}$ \\
\hline \multirow{3}{*}{ Right laterotrusion $\bullet$ Desna laterotruzija } & $\mathrm{X}$ & 26.8 & 8.8 & 0.1198 \\
\hline & $\mathrm{Y}$ & 61.5 & 1.4 & $<0.0001^{*}$ \\
\hline & $\mathrm{Z}$ & 4.7 & 5.2 & 0.6283 \\
\hline \multirow{3}{*}{ Left laterotrusion $\bullet$ Lijeva laterotruzija } & $\mathrm{X}$ & 24.7 & 7.3 & 0.1193 \\
\hline & $\mathrm{Y}$ & 76.9 & 80.0 & 0.9981 \\
\hline & Z & 81.8 & 0.0 & $<0.0001^{*}$ \\
\hline \multirow{3}{*}{ Central relation $\bullet$ Centrična relacija } & $\mathrm{X}$ & 28.3 & 8.7 & 0.0897 \\
\hline & $\mathrm{Y}$ & 68.2 & 0.0 & $<0.0001^{*}$ \\
\hline & Z & 57.1 & 12.5 & $0.0005^{*}$ \\
\hline
\end{tabular}




\section{Discussion}

Despite generally accepted assumptions that the occlusal splint is the treatment of choice for bruxism, there is still a lack of quality evidence to explain its exact impact. The unclear mechanism and the effects of splints in bruxism treatment are not surprising, since the exact etiology of bruxism, i.e. the exact cause of the central nervous system activation during sleep, has not been clarified so far $(7,17)$. In this pilot study, the impact of the occlusal splint treatment on changes in mandibular border movements and those in condyle position in subjects with bruxism was examined during 8 weeks. Subsequently, this impact was compared with the control group, for which no similar studies were found in the reviewed literature. The measurements for all positions other than CR were performed without a splint, since measurements with splints inside the mouth do not always show correct results of mandibular movements and condyle position, as they depend on the thickness of the splint (changed vertical dimension) and its occlusal design (18). The only measurement with a splint in the mouth was performed for the CR position because the splint was initially fabricated in CR. The results of this study have shown that all measured mandibular movements and changes in the condyle position indicate an increase in values during treatment. There was no statistically significant difference established for any of the abovementioned parameters. The data obtained for border movements were expected because all subjects with TMD, myofascial pain, and muscle spasm (16) or with some other condition limiting mandibular movements were excluded from this study. As opposed to this, bruxism does not limit them. It only causes hypertrophy of the masticatory muscles $(2,17)$. Agerberg et al. (19) have suggested considering the value of $40 \mathrm{~mm}$ as normal for maximum unforced mouth opening and $5 \mathrm{~mm}$ for laterotrusions. In this study, before the beginning of the treatment, mandibular movements in subjects with bruxism averaged $43.69 \mathrm{~mm}$ for mouth opening, $8.28 \mathrm{~mm}$ for left laterotrusion, and $8.17 \mathrm{~mm}$ for right laterotrusion. The increase in all mandibular movements after splint treatment established in this study was confirmed in similar studies in asymptomatic subjects, as well as in subjects with bruxism (12) and TMD $(20,21)$. In this study, the highest increase in mandibular movements was found for mouth opening, which is consistent with the research by Serrano et al. (12) and Katyayana et al. (20). The initial values of condyle displacement at mouth opening approach the values in asymptomatic patients from previously published studies $(22,23)$ only after the occlusal splint treatment. Although they do not reach their values, splint treatment in subjects with bruxism results in increased mandibular and condylar movements. If this pilot study had been continued, it would have shown the effect of treatment duration on movements and their possible approaching to the values in asymptomatic subjects. No studies examining the differences in condyle displacement in subjects with bruxism at mouth opening after splint treatment were found in the available literature. In this study, the highest increase of $13.8 \%$ was established for the left condyle at mouth opening, whereas the increase for

\section{Rasprava}

Unatoč općeprihvaćenom izboru terapije bruksizma okluzijskom udlagama, još nedostaju kvalitetni dokazi za objašnjenje točnog utjecaja same udlage. Nejasan mehanizam i učinak djelovanja udlage kod bruksizma ne iznenađuje, jer dosad nije razriješena točna etiologija bruksizma, odnosno točan uzrok aktivacije središnjega živčanog sustava tijekom spavanja $(7,17)$. U ovom pilot-istraživanju u 8 tjedana ispitan je utjecaj na promjene graničnih kretnji mandibule te promjene u položaju kondila nakon terapije okluzijskom udlagom kod ispitanika s bruksizmom te je uspoređen $s$ kontrolnom skupinom, za što nisu pronađena slična istraživanja u pregledanoj literaturi. Mjerenja za sve položaje, osim CRa, obavljena su bez udlage u ustima jer rezultati mjerenja $s$ udlagom ne pokazuju nužno ispravne rezultate kretnji donje čeljusti i položaja kondila zato što su pod utjecajem debljine udlage (promijenjena vertikalna dimenzija) i okluzijskoga dizajna same udlage (18). Jedino mjerenje s udlagom u ustima učinjeno je za položaj CR jer je sama udlaga inicijalno izrađena u CR-u. Rezultati ovog istraživanja pokazuju da sve mjerene kretnje donje čeljusti i promjene položaja kondila pokazuju porast vrijednosti tijekom terapije. Ni u jednom parametru nije utvrđena statistički značajna razlika. Navedeni podatci za granične kretnje očekivani su jer su iz ovog istraživanja bili isključeni svi ispitanici s TMP-om, miofascijalnom boli, grčem mišića (16) ili nekim drugim stanjem koje ograničuje kretnje donje čeljusti, dok ih bruksizam ne ograničuje i kod žvačnih mišića uzrokuje samo hipertrofiju $(2,17)$. Agerberg i suradnici (19) predlažu da se $40 \mathrm{~mm}$ smatra normalnim za maksimalno nenasilno otvaranje usta, a za laterotruzije $5 \mathrm{~mm}$. U ovom istraživanju su prije početka terapije kretnje donje čeljusti kod ispitanika s bruksizmom iznosile prosječno 43,69 mm za otvaranje usta, za lijevu laterotruziju $8,28 \mathrm{~mm}$, a za desnu laterotruziju $8,17 \mathrm{~mm}$. Povećanje svih kretnji mandibule nakon terapije udlagom utvrđeno u ovom istraživanju potvrđeno je u sličnim istraživanjima kod asimptomatskih ispitanika i ispitanika s bruksizmom (12) te kod ispitanika s TMP-om $(20,21)$. U ovom istraživanju najveće povećanje kretnji donje čeljusti zabilježeno je pri otvaranju usta, što je u skladu s istraživanjima Serrana i suradnika (12) te Katyayana i suradnika (20). Inicijalne vrijednosti pomaka kondila pri otvaranju usta u ovom se istraživanju tek nakon terapije udlagom približavaju vrijednostima asimptomatskih ispitanika utvrđenima u već objavljenim istraživanjima (22, 23). Iako se ne dostižu vrijednosti asimptomatskih ispitanika, terapija udlagom kod ispitanika s bruksizmom pokazuje povećanje svih kretnji donje čeljusti i pomak kondila te bi nastavak ove pilot-studije pokazao učinak trajanja terapije na njih i eventualno približavanje vrijednostima kod asimptomatskih ispitanika. Pregledom literature nisu pronađena istraživanja čiji su autori ispitivali razlike u pomaku samog kondila kod ispitanika s bruksizmom pri otvaranju usta nakon terapije udlagom. U ovom je istraživanju najveće povećanje zabilježeno kod lijevog kondila pri otvaranju od 13,8 \% a kod desnog zabilježeno je povećanje od 8,9\%. U skladu sa sličnim istraživanjima $(24-26)$, i u ovomu su pomaci položaja kondila očekivano mali i ograničeni zglobnim prostorom, odnosom 
the right condyle amounted to $8.9 \%$. Following similar studies (24-26), condyle displacements are, as expected, small and limited by joint space, disc-condyle relationship and disc adaptability. The ideal protrusion movement should be without the condyle displacement in the transversal plane, which has been rarely found in the research so far. Therefore Slavicek (27) described a displacement in the transversal plane (z) of $0.2-0.3 \mathrm{~mm}$ as expected. In this study, a transversal displacement $(\mathrm{z})$ of $0.23 \mathrm{~mm}$ remained unchanged after the splint treatment in the experimental group, whereas a change of $0.07 \mathrm{~mm}$ was found in the control group, which indicates that the use of splints does not influence transversal condylar movements in protrusion. Unlike the transversal plane (z), the changes in the horizontal $(\mathrm{x})$ and vertical $(\mathrm{y})$ plane were found both in the experimental and control group. The greatest change of $18.5 \%$ was found in the $\mathrm{x}$-axis of the experimental group, referring to a displacement in the forward direction. These results cannot be compared with research on protrusion displacement in asymptomatic or symptomatic subjects because they were either investigated without the splint treatment or by another test method, and the objective of research was mainly to investigate into the condylar path rather than spatial displacement with respect to the initial reference position, for which the values were higher than the results obtained in this study (28-30). Similar studies were not found in the reviewed literature. The condyle position during left and right laterotrusion changed both in the horizontal (x) and vertical (y) plane, reaching a larger distance from the $\mathrm{MI}$ in the experimental than in the control group. The values for the transversal $(\mathrm{z})$ plane remained the same for the right laterotrusion and were increased for the left laterotrusion. Apart from changes in the occlusal tooth surfaces caused by splints affecting lateral movements (31) and increasing laterotrusion, the obtained results draw to the conclusion that the splint treatment affected condyle position displacement in both the experimental and control group in at least two planes. The initial difference, as well as the difference after the treatment in the condyle position between the reference position and the $\mathrm{CR}$, was smaller than the value of mean deviation confirmed in previous studies (32). As expected, the changes in condyle position after the splint treatment were the smallest for both subject groups in the CR position. Although minimal, the established changes have confirmed the fact that the CR position is not a fixed, static position, but that the $\mathrm{CR}$ is a range of possible positions dependent on the symmetrical mandibular muscle activity with a minimum level of muscle tone (27). In the interpretation of the results of larger condylar displacement in the CR in the experimental group, a change in the occlusal surface of the splint, irrespective of its fabrication material, should also be considered due to wear caused by parafunctional movements (33). A study comparing the effect of occlusal splints on the condyle position in subjects with TMD and asymptomatic control group showed that splints influenced the condyle position to a greater extent in the experimental group than in the control group after 10 weeks $(34,35)$. This study also showed a greater impact of the occlusal splint treatment in 10 out of 14 measured parameters of the condylar position in subjects disk - kondil i sposobnošću prilagodbe diska. Idealna protruzijska kretnja trebala bi biti bez pomaka kondila u transverzalnoj ravnini, što se u istraživanjima rijetko nalazi, te je Slaviček (27) opisao pomak u transverzalnoj ravnini (z) od 0,2 do 0,3 kao očekivan. $U$ našem istraživanju transverzalni pomak (z) od 0,23 mm nije se promijenio nakon terapije udlagom u ispitnoj skupini, a u kontrolnoj je zabilježena promjena od $0,07 \mathrm{~mm}$, što pokazuje da korištenje udlaga ne utječe na transverzalne kretnje kondila u protruziji. Na razliku od transverzalne ravnine $(\mathrm{z})$, promjene su utvrđene i horizontalnoj (x) i u vertikalnoj (y) ravnini i u ispitnoj i u kontrolnoj skupini. Najveća promjena od $18,5 \%$ ustanovljena tje u x osi ispitne skupine, gdje je išla u smjeru većeg pomaka kondila prema naprijed. Ti se rezultati ne mogu usporediti s istraživanjima na asimptomatskim ili simptomatskim ispitanicima kod kojih se ispitivao pomak u protruziji jer su ispitivani bez terapije udlagom ili drugom metodom ispitivanja, a većinom se provodilo istraživanje putanje kondila, a ne prostornog pomaka u odnosu prema referentnom početnom položaju gdje su iznosi veći od rezultata dobivenih u ovom istraživanju (28 -30). Slična istraživanja nisu pronađena u pregledanoj literaturi. Položaj kondila tijekom lijeve i desne laterotruzije promijenio se i u horizontalnoj (x) i u vertikalnoj (y) ravnini u smjeru većeg udaljavanja od MI-ja u ispitnoj skupini negoli u kontrolnoj skupini. Vrijednosti za transverzalnu (z) ravninu za desnu laterotruziju ostale su jednake, a za lijevu su se također povećale. Ako se izuzme promjena okluzalnih dodira zuba zbog korištenja udlage koja utječe na lateralne kretnje (31) kao čimbenik povećanja laterotruzije, prema dobivenim rezultatima zaključuje se da je terapija udlagom utjecala na pomak položaja kondila i u ispitnoj i u kontrolnoj skupini u barem dvjema ravninama. Inicijalna razlika, a i razlika nakon terapije u položaju kondila između referentnog položaja i CR-a, manja je od iznosa srednjeg odstupanja potvrđenog u dosadašnjim istraživanjima (32). Promjene položaja kondila nakon terapije udlagom očekivano su najmanje i u ispitnoj i u kontrolnoj skupini u položaju CR-a. Iako minimalne, pronađene promjene potvrđuju da položaj CR-a nije fiksiran statički položaj, nego da je CR raspon mogućih položaja ovisnih o simetričnom djelovanju mišića donje čeljusti s minimalnom razinom mišićnog tonusa (27). U interpretaciji rezultata većeg pomaka kondila u CR-u u ispitnoj skupini treba uzeti u obzir i promjenu okluzalne površine udlage, neovisno o upotrijebljenom materijalu, a uzrok je trošenje zbog parafunkcijskih kretnji (33). Istraživanje usporedbe utjecaja okluzijske udlage na položaj kondila kod ispitanika s TMD-om i kontrolne asimptomatske skupine pokazalo je da udlaga više utječe na položaj kondila ispitne skupine u odnosu prema kontrolnoj nakon 10 tjedana $(34,35)$. U našem istraživanju kod ispitanika s bruksizmom također je uočeno da je utjecaj terapije okluzijskom udlagom bio veći u 10 od 14 mjerenih parametara položaja kondila (tablica 1.) kod ispitanika s bruksizmom u odnosu prema kontrolnoj skupini. Dva parametra ispitne skupine imala su promjenu manju od $1 \%$, oba pri protruzijskoj kretnji, što je očekivano $(26-27)$. Kod 5 od 14 uspoređenih parametara položaja kondila utvrđena je statistički značajna razlika, od toga 3 u vertikalnoj osi i 2 u transverzalnoj. U horizontalnoj osi, pri svim kretnjama i položaji- 
with bruxism than in the control group (Table 1). Two parameters of the control group showed a change of less than $1 \%$ at protrusion, which was also expected (26-27). A statistically significant difference was found in 5 out of 14 compared condyle position parameters, 3 of which were in the vertical axis and 2 in the transversal axis. No statistically significant difference was found in the horizontal axis for all movements and positions. One limitation of this pilot study is a small number of subjects, which reduces the strength of our conclusions. However, this study is a part of a full scale study which is now in progress, thus providing us with more extensive information about the subject.

\section{Conclusion}

Although the current pilot study included a small number of subjects, it has proved that there is an impact of the occlusal splint treatment on mandibular border movements in subjects with bruxism and, also, an impact on a greater change in the condyle position in subjects with bruxism than in the control group. The obtained results are encouraging for further research, in a way to include a larger number of subjects in the experimental and control group and to prolong the duration of the occlusal splint treatment.

\section{Conflict of interest}

There was no conflict of interest in this study.

\section{Author's contribution}

J.Š. - principal author of the paper and research, gathered patients, conducted measurements, and wrote the entire article; S. C. - assisted in the use of measuring instruments and in making measurements on patients; S.K.S. - assisted in statistical data processing; M.V. - assisted in writing the article and assisted in collecting literature; N.D. - devised a research plan and assisted in implementation. ma, nije ustanovljena statistički značajna razlika. Ograničenje ovog pilot-istraživanja je mali broj ispitanika, što umanjuje snagu naših zaključaka. No ovo je istraživanje dio opsežnijeg istraživanja koje je u tijeku i koje će nam omogućiti prikupljanje opsežnih informacija o navedenoj temi.

\section{Zaključak}

Iako na malom broju ispitanika, u ovom pilot-istraživanju dokazan je utjecaj terapije udlagom na granične kretnje mandibule kod ispitanika s bruksizmom te na veću promjenu položaja kondila kod ispitanika s bruksizmom u odnosu prema zdravim ispitanicima. Dobiveni rezultati potiču na nastavak istraživanja s povećanim brojem ispitanika u ispitnoj i kontrolnoj skupini te duljom terapijom udlagom.

\section{Sukob interesa}

Autori nisu bili u sukobu interesa.

\section{Doprinos autora}

J. Š. - glavni autor rada i istraživanja, skupio je pacijente, obavio mjerenja te napisao cijeli članak; S. C. - pomogao je pri korištenju mjernih instrumenata i provedbi mjerenja na pacijentima; S. K. Š. - pomogla je pri statističkoj obradi podataka; M. V. - pomogao je pri pisanju članka i tijekom skupljanja literature; N. D. - osmislio je plan istraživanja i pomogao u provedbi

\section{Sažetak}

Svrha rada: Svrha ovog pilot-istraživanja bila je ispitati utjecaj terapije okluzijskom udlagom na granične kretnje donje čeljusti te položaj kondila kod ispitanika s bruksizmom. Materijal i postupci: U istraživanje je bilo uključeno 9 ispitanika s dijagnosticiranim bruksizmom (srednja dob 28,7 godina) i 9 ispitanika u kontrolnoj skupini (srednja dob 30,5 godina). Svi su bili punoljetni, eugnati s dentoalveolarnom klasom I prema Angleu, bez postojećih protetičkih radova, bez prijašnje ili sadašnje ortodontske terapije, prijašnjih kirurških zahvata u području temporomandibularnog zgloba te bez neke sistemske bolesti. Za sve ispitanike u objema skupinama izrađena je relaksacijska okluzijska udlaga standardiziranim postupkom koju su nosili 8 tjedana. Za to su vrijeme obavljena, uz inicijalno, još 3 mjerenja incizalnog otvaranja (IO), otvaranja lijevog kondila (OLC), otvaranja desnog kondila (ORC), lijeve laterotruzije (LLI) i desne laterotruzije (LRI) (nakon 2, 4 i 8 tjedana), koristeći se ultrazvučnim uređajem za snimanje kretnji donje čeljusti Arcus Digma II (Kavo). Istim uređajem ispitana je promjena položaja kondila pri protruziji, lijeve i desne laterotruzije te u položaju centrične relacije (CR) na početku istraživanja i zatim nakon 8 tjedana koristeći se položajem maksimalne interkuspidacije kao referentnim. Kontinuirane varijable opisane su s pomoću osnovnih statističkih parametara, a statistička značajnost razlika između varijabli provjerena je t-testom i $\chi 2$ testom $(p<0,05)$. Rezultati: Vrijednosti za IO, OLC, ORC, LLI LRI povećane su nakon 8-tjednog nošenja udlage te je najveće povećanje zabilježeno kod OLC-a -- za 13,8 \%. Ni za jednu promjenu iznosa graničnih kretnji nije utvrđena statistički značajna razlika $(p<0,05)$. Promjene položaja kondila pri protruziji, lijeve i desne laterotruzije te u položaju centrične relacije (CR) bile su veće u ispitnoj skupini u 10 od 14 mjerenih parametara u odnosu prema kontrolnoj skupini te je u 5 od 14 mjernih parametara ustanovljena statistički značajna razlika nakon terapije udlagom. Zaključak: U ovom pilot-istraživanju dokazan je utjecaj terapije udlagom na granične kretnje mandibule kod ispitanika s bruksizmom povećanjem raspona kretnji. Također je utvrđena veća promjena položaja kondila kod ispitanika s bruksizmom u odnosu prema zdravima.
Zaprimljen: 28. travnja 2020.

Prihvaćen: 24. kolovoza 2020

Adresa za dopisivanje Josip Škaričić

Privatna ordinacija u Splitu Student doktorskog studija Stomatološkog fakulteta Sveučilišta u Zagrebu

josip.skaricic@gmail.com

Ključne riječi

bruksizam, okluzijska udlaga, kondil mandibule 


\section{References}

1. International Classification of Sleep Disorders. American Academy of Sleep Medicine. Sleep related bruxism. 3rd ed. West chester, Darien, Illinois: American Academy of Sleep Medicine; 2014:303-311.

2. Lobbezoo F, Ahlberg J, Raphael KG, Wetselaar P, Glaros AG, Kato T, et al. International consensus on the assessment of bruxism: Report of a work in progress. J Oral Rehabil. 2018 Nov;45(11):837844.

3. Takahashi H, Masaki C, Makino M, Yoshida M, Mukaibo T, Kondo $Y$, et al. Management of sleep-time masticatory muscle activity using stabilisation splints affects psychological stress. J Oral Rehabil. 2013;40:892-899.

4. Ilovar S, Zolger D, Castrillon E, Car J, Huckvale K. Biofeedback for treatment of awake and sleep bruxism in adults: systematic review protocol. Syst Rev. 2014 May;2;3:42.

5. Glass EG, Glaros AG, MacGlynn FD. Myofacial dysfunction: treatments used by ADA members. Cranio. 1993 Jan;11(1):25-9.

6. Pierce CJ, Chrisman K, Bennett ME, Close JM. Stress, anticipatory stress, and psychologic measures related to sleep bruxism. J Orofac Pain. Winter 1995;9(1):51-6.

7. Dao TT, Lavigne GJ. Oral splints: the crutches for temporomandibular disorders and bruxism? Crit Rev Oral Biol Med. 1998;9(3):345-61.

8. Sójka A, Huber J, Kaczmarek E, Hędzelek W. Evaluation of Man dibular Movement Functions Using Instrumental Ultrasound System. J Prosthodont. 2017 Feb;26(2):123-128.

9. Stiesch-Scholz M, Demling A, Rossbach A. Reproducibility of jaw movements in patients with craniomandibular disorders. J Oral Rehabil. 2006 Nov;33(11):807-12.

10. Čimić S. Kliničko istraživanje kretnji položaja donje čeljusti ultrazvučnim postupkom [dissertation]. Zagreb: Stomatološki fakultet; 2014.

11. Čimić S, Kraljević Šimunković S, Badel T, Dulčić N, Alajbeg I, Ćatić A. Measurements of the sagittal condylar inclination: intraindividual variations. Cranio. $2014 \mathrm{Apr}$;32(2):104-9.

12. Serrano Pde O, Faot F, Del Bel Cury AA, Rodrigues Garcia RC. Effect of dental wear, stabilization appliance and anterior tooth reconstruction on mandibular movements during speech. Braz Dent J. 2008;19(2):151-8.

13. Obrez A, Gallo LM. Anatomy and function of the TMJ. In: Laskin DM, Greene CS, Hylander WL, editors. TMDs: An Evidence-Based Approach to Diagnosis and Treatment. Hanover Park: Quintessence Publishing Co, 2006;39-41.

14. Shetty S, Pitti V, Satish Babu CL, Surendra Kumar GP, Deepthi BC. Bruxism: a literature review. J Indian Prosthodont Soc. 2010 Sep;10(3):141-8.

15. Pintado MR, Anderson GC, De Long R, Douglas WH. Variation in tooth wear in young adults over a two-year period. J Prosthet Dent. 1997;77:313-320

16. MeSH Browser [database on the Internet]. Čelić R, Dulčić N. Dijagnostički kriteriji za istraživanje temporomandibularnih poremećaja DKI/TMP. 2004. Available from: https://ubwp.buffalo.edu/rdc-tmdinternational/wp-content/uploads/ sites/58/2017/01/RDC-Croatian.pdf

17. Beddis H, Pemberton M, Davies S. Sleep bruxism: an overview for clinicians. Br Dent J. 2018;225(6):497-501.

18. Demling A, Fauska K, Ismail F, Stiesch M. A comparison of change in condylar position in asymptomatic volunteers utilizing a stabilization and a pivot appliance. J Indian Prosthodont Soc. 2010 Sep;10(3):141-8.
19. Agerberg G. Maximal mandibular movements in young men and women. Sven Tandlak Tidskr. 1974 Mar;67(2):81-100.

20. Katyayan PA, Katyayan MK, Shah RJ, Patel G. Efficacy of appliance therapy on temporomandibular disorder related facial pain and mandibular mobility: a randomized controlled study. J Indian Prosthodont Soc. 2014;14(3):251-261.

21. Ekberg E, Nilner M. Treatment outcome of appliance therapy in temporomandibular disorder patients with myofascial pain after 6 and 12 months. Acta Odontol Scand. 2004 Dec;62(6):343-9.

22. Fukui T, Tsuruta M, Murata K, Wakimoto Y, Tokiwa H, Kuwahara Y. Correlation between facial morphology, mouth opening ability, and condylar movement during opening-closing jaw movements in female adults with normal occlusion. Eur J Orthod. 2002;24(4):327-336.

23. Travers KH, Buschang PH, Hayasaki H, Throckmorton GS. Associations between incisor and mandibular condylar movements during maximum mouth opening in humans. Arch Oral Biol. 2000 Apr;45(4):267-75.

24. Santosa RE, Aziz M, Whittle T, Wanigaratne K, Klineberg U. The influence of the leaf gauge and anterior jig on jaw muscle electromyography and condylar head displacement: a pilot study. Aust Dent J. 2006 Mar;51(1):33-41.

25. Linsen SS, Stark H, Klitzschmüller M. Reproducibility of condyle position and influence of splint therapy on different registration techniques in asymptomatic volunteers. Cranio. 2013 Jan;31(1):32-9.

26. Čimić S, Kraljević Šimunković S, Simonić Kocijan S, Matijević J, Dulčić N, Ćatić A. Articulator-related registration and analysis of sagittal condylar inclination. Acta Clin Croat. 2015;54(3):432437.

27. Slavicek R. Clinical and instrumental functional analysis for diagnosis and treatment planning. Part 5. Axiography. J Clin Orthod. 1988;22(10):656-667.

28. Peck CC, Murray GM, Johnson CW, Klineberg IJ. Trajectories of condylar points during nonworking side and protrusive movements of the mandible. J Prosthet Dent. 1999;82(3):322-31.

29. Zimmer B, Jäger A, Kubein-Meesenburg D. Comparison of "normal' TMJ-function in Class I, II, and III individuals. Eur J Orthod. 1991;13(1):27-34.

30. Landes CA, Sader R. Sonographic evaluation of the ranges of condylar translation and of temporomandibular joint space as well as first comparison with symptomatic joints. J Craniomaxillofac Surg. 2007;35(8):374-81.

31. Ogawa M, Ogawa T, Koyano K, Suetsugu T. Effect of altered canine guidance on condylar movement during laterotrusion. Int J Prosthodont. 1998;11(2):139-44.

32. Linsen SS, Stark H, Samai A. The influence of different registration techniques on condyle displacement and electromyographic activity in stomatognathically healthy subjects: a prospective study. J Prosthet Dent. 2012;107(1):47-54.

33. Reyes-Sevilla M, Kuijs RH, Werner A, Kleverlaan CJ, Lobbezoo F. Comparison of wear between occlusal splint materials and resin composite materials. J Oral Rehabil. 2018 Jul;45(7):539-544.

34. Ekberg EC, Sabet ME, Petersson A, Nilner M. Occlusal appliance therapy in a short-term perspective in patients with temporomandibular disorders correlated to condyle position. Int J Prosthodont. May-Jun 1998;11(3):263-8.

35. Limchaichana N, Nilsson H, Petersson A, Ekberg E. Resilient appliance-therapy treatment outcome in patients with TMD pain correlated to MRI-determined changes in condyle position. 